\title{
Are serum levels of 25-hydroxy vitamin $D$ reduced following orchiectomy in testicular cancer patients?
}

\author{
Klaus-Peter Dieckmann ${ }^{1 *}$ (D, Osama Andura ${ }^{1}$, Uwe Pichlmeier ${ }^{2}$, Klaus Martin Otte ${ }^{3}$, Hendrik Isbarn ${ }^{4}$ and \\ Christian Wülfing ${ }^{1}$
}

\begin{abstract}
Background: The testis represents one place where the progenitor of vitamin D is converted into its active form. Loss of one testis was suggested to result in reduced vitamin D serum levels. Vitamin D deficiency would represent a significant health problem in the long-term course of patients with testicular germ cell tumors (GCTs) since most of them survive. The purpose of this study was to look to the serum 25(OH)-Vitamin D (25OHD) levels in patients with GCTs before and after orchiectomy. A total of 177 GCT patients underwent measurements of serum 25OHD levels, thereof 83 with preoperative measurements and 94 with measurements at six particular time-points from immediate postoperatively to $>24$ months. Longitudinal assessments of $25 \mathrm{OHD}$ serum levels were performed in individual patients with repeated measurements. A second analysis involved patient cohorts with measurements at six postoperative time-points. Serum levels of patients were also compared with 2 control groups, one consisting of 84 patients with non-neoplastic testicular diseases and another with 237 patients with non-neoplastic urologic diseases. We also looked to associations of $250 \mathrm{HD}$ levels with levels of testosterone, follicle stimulating hormone (FSH), age, histology of GCT and season. Descriptive statistical methods were employed to compare groups and to analyze changes over time.
\end{abstract}

Results: Normal serum levels of 25OHD were found in 21.7\%, 23.1\%, 20.2\%, 21.9\% in GCT patients preoperatively, after $>2$ years, in control group 1 and control group 2, respectively. Levels were significantly higher in spring and summer, but no association was found with other parameters. We found a significant transient decrease of $250 \mathrm{OD}$ levels with a nadir at 6-12 months after orchiectomy and a recovery thereafter.

Conclusion: Contrasting with previous studies we found no permanent reduction of serum 25OHD levels after orchiectomy but transient postoperative drop of $250 \mathrm{HD}$ levels. There were no associations of $25 \mathrm{OHD}$ levels with age, and levels of testosterone or FSH. Our results may point to a particular role of the testis in vitamin D metabolism and may thus enhance the understanding of the diverse physiological roles of the testis.

Keywords: Testis, Germ cell tumor, Vitamin D, Orchiectomy, Hypovitaminosis, 25(OH)-Vitamin D

\footnotetext{
* Correspondence: Dieckmannkp@t-online.de

'Department of Urology, Testis Cancer Unit, Asklepios Klinik Altona, Paul

Ehrlich Strasse 1, Hamburg, Germany

Full list of author information is available at the end of the article
}

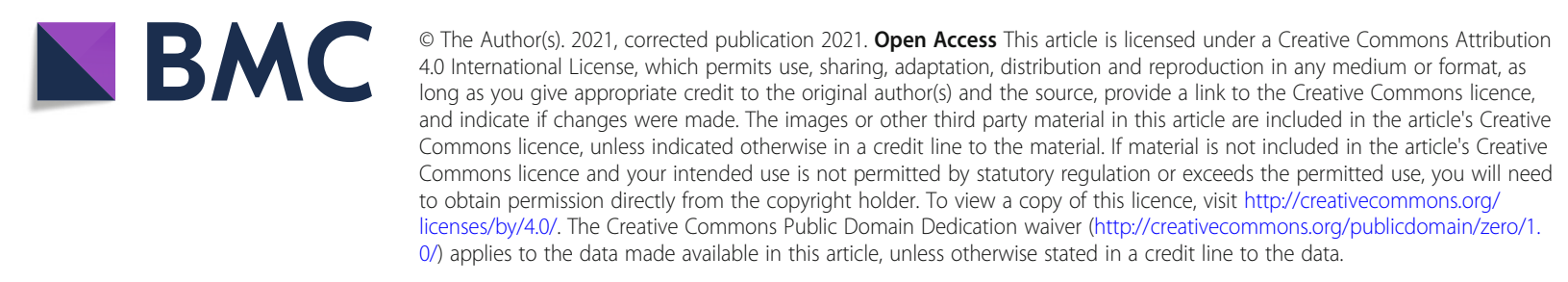




\section{Résumé}

Contexte: Le testicule représente un lieu où le précurseur de la vitamine D est converti en sa forme active. Il a été suggéré que la perte d'un testicule pouvait induire une réduction des taux sériques de vitamine $D$. La carence en vitamine $D$ représenterait un problème de santé important à long terme pour les patients présentant des tumeurs testiculaires à cellules germinales (TCG) puisque la plupart d'entre eux survivent. Le but de cette étude était de se tourner vers les taux sériques de 25(OH)-Vitamine D (25OHD) chez les patients présentant des TCG, avant et après orchidectomie. Au total, 177 patients avec TCG ont subi des mesures des taux sériques de 25OHD, dont 83 avec mesures préopératoires et 94 avec des mesures à six points de temps particuliers, de l'immédiat postopératoire jusqu'à plus de 24 mois. Des évaluations longitudinales des taux sériques de 250HD ont été réalisées individuellement chez les patients avec des mesures répétées. Une seconde analyse a impliqué des cohortes de patients avec des mesures à six points de temps postopératoires. Les taux sériques des patients ont également été comparés à ceux de 2 groupes témoins, l'un composé de 84 patients atteints de maladies testiculaires non néoplasiques, et l'autre de 237 patients atteints de maladies urologiques non néoplasiques. Nous nous sommes également penchés sur les associations des taux de 250HD avec les taux de testostérone, d'hormone folliculostimulante (FSH), l'âge, I'histologie de la TCG et la saison. Des méthodes statistiques descriptives ont été utilisées pour comparer les groupes et analyser les changements au fil du temps.

Résultats: Des taux sériques normaux de $250 \mathrm{HD}$ ont été trouvés chez 21,7\%,23,1\%,20,2\%, et 21,9\% des patients avec GCT, respectivement en préopératoire et après $>2$ ans, ainsi que chez les patients du groupe témoin 1 et du groupe témoin 2. Les taux ont été significativement plus élevés au printemps et en été, mais aucune association n'a été observée avec d'autres paramètres. Nous avons retrouvé une diminution transitoire significative des taux de 25OHD avec un nadir à 6-12 mois après orchiectomie et un rétablissement par la suite.

Conclusion: Contrairement aux études précédentes, nous n'avons trouvé aucune réduction permanente des niveaux de sérum 250HD après orchiectomie, mais une baisse postopératoire transitoire des taux de 25OHD. II n'y avait pas d'associations entre les taux de 25OHD et l'âge, ni avec les taux de testostérone ou de FSH. Nos résultats peuvent mettre en avant un rôle particulier du testicule dans le métabolisme de la vitamine $D$ et peuvent ainsi améliorer la compréhension des divers rôles physiologiques des testicules.

Mots-clés: Testicules, Tumeur à Cellules Germinales, Vitamine D, Orchiectomie, Hypovitaminosis, 25(OH)-Vitamine D

\section{Introduction}

Testicular germ cell tumors (GCTs) represent one of the most frequent malignancies in men aged younger than 50 years [1]. The over-all cure rate is more than $90 \%$ and most of the patients with GCT will enjoy a long life-expectancy despite the diagnosis of cancer [2]. Therefore, physicians caring for GCT patients are increasingly looking for long-term consequences of treatment, mainly second malignant neoplasms, cardiovascular disease and endocrinological disorders [3-5]. Recently, dysregulation of the vitamin D metabolism secondary to cancer-related loss of one testicle has come into the focus [6]. As vitamin D plays an essential role in bone health and in a large variety of other metabolic pathways [7-11] vitamin D deficiency would constitute a significant health problem in long-term survivors of GCT patients that caregivers of these patients should be aware of [12].

Physiologically, the progenitor of vitamin D, cholecalciferol, needs two hydroxylation steps to convert into its active form, the $1 \alpha, 25$-dihydroxy vitamin $\mathrm{D}$. The first hydroxylation step takes place in the liver and is mediated by CYP2R1, while the second hydroxylation is performed in the kidney under guidance of CYP27B1 $[7-9,13,14]$. Noteworthy, both enzymes CYP2R1 and CYP27B1, are found in large amounts in testicular tissue [15]. Immunohistologically, the enzymes are located in both germ cells and Leydig cells, and notably, reduced expression had been noted in men with impaired spermatogenesis [16, 17]. Furthermore, vitamin D receptors have been detected in germ cells and Sertoli cells [18, 19]. In animal experiments it has been shown that hepatic synthesis of CYP2R1 increases after castration [20]. Finally, an association of vitamin D serum levels with testosterone levels have been observed in elderly men [21], and vitamin D levels are associated with semen quality [22]. In aggregate, there is accumulating evidence for the involvement of the testicular compartment in the metabolism of vitamin $\mathrm{D}[16,23]$.

Clinically, reduced vitamin D serum levels in men with testicular diseases were first reported by Foresta et al. in 2010 [6, 8, 24]. Two subsequent studies confirmed vitamin $D$ deficiency in long-term survivors of GCT [25, 26]. 
The goal of the present investigation was to evaluate 25-hydroxyvitamin D (25OHD) serum levels in GCT patients prior to orchiectomy and during the later course. Our study hypotheses were as follows: (1) Loss of testicular parenchyma due to surgery is associated with decreased 25OHD serum level, (2) loss of both testicles will cause even lower 25OHD levels, (3) 25OHD deficiency will increase with time interval from testicular loss, (4) impaired spermatogenesis evidenced by increased levels of follicle stimulating hormone (FSH) is associated with 25OHD deficiency. In addition, we looked to possible associations of 25OHD deficiency with histology of GCT, patient age, season of the year, and testosterone-levels.

\section{Materials and methods Patients, controls}

During 2018-2019, all patients undergoing orchiectomy for testicular GCT underwent preoperative measurements of 25-hydroxy vitamin D (25OHD) serum levels as part of the routine laboratory work-up ("base-line" measurement, "time-point 0 "). Measurements were also done shortly postoperatively (p/o; "time-point 1 "), and again at follow-up visits after 3 months (time-point 2), 6, 12 , 24, and more than 24 months (time-point 6), respectively. Repeat measurements in individual patients were accomplished only in a few patients because most of the patients had their follow-up examinations after orchiectomy done elsewhere. Therefore, GCT patients who had orchiectomy performed at other institutions or before 2018 were enrolled for postoperative measurements of 25OHD serum levels with specifying the particular time-point after surgery. Some of whom underwent also repeat measurements.

As one of our study hypotheses was that orchiectomyrelated 25OHD deficiency will increase with time from surgery, we defined a subgroup of patients where only the latest measurement available in each patient was employed for analysis. This subgroup is characterized as the "GCT main group".

Controls consisted of patients with non-neoplastic scrotal diseases, e.g. epididymitis, varicocele, spermatocele, or hydrocele ("cohort 2"). A second control group ("cohort 3") consisted of male urologic patients with non-testicular and non-neoplastic diseases, mainly urinary tract infection, stone disease, benign prostatic disease, and benign penile disease. All of the controls had only one measurement of $25 \mathrm{OHD}$ serum levels.

The following data were registered in GCT patients along with the serum level of 25OHD: time-point of measurement (time-points 0-6), histology of testicular tumor (seminoma or nonseminoma), season (1: January-March; 2: April-June; 3: July- September; 4: October - December), and serum levels of testosterone and follicle stimulating hormone (FSH) which always were measured as part of the routine care of GCT patients. In controls, no additional data were recorded.

All patients had given informed consent. Enquiry at the local ethical committee (Ärztekammer Hamburg, PV7288) revealed that no formal ethical approval was required because only anonymized data generated upon routine clinical care were analyzed. All study activities had been conducted according to the Declaration of Helsinki of the World Medical Association (as amended by the 64th General Assembly, 2013).

\section{Laboratory technology}

Circulating serum 25OHD levels were measured by chemiluminescence micro-particle immunoassay (CMIA) on the Abbott Architect system. According to the serum levels measured, we defined the following categories of 25OHD levels: > 30ng/ml: normal; $20-30 \mathrm{ng} / \mathrm{ml}$ : insufficient (S1); $10-20 \mathrm{ng} / \mathrm{ml}$ : inadequate $(\mathrm{S} 2) ;<10 \mathrm{ng} / \mathrm{ml}$ : deficient (S3).

Table 1 Characteristics of study population

\begin{tabular}{|c|c|c|c|c|c|}
\hline & $\mathbf{N}$ & Age median (years) & Q1 (years) & Q3 (years) & min; max (years) \\
\hline GCT patients & 177 & 38 & 33 & 46 & $19 ; 80$ \\
\hline Seminoma & 112 & 39 & 34.5 & 48.5 & $19 ; 80$ \\
\hline Nonseminoma & 65 & 35 & 29 & 41 & $19 ; 62$ \\
\hline preoperative subgroup & 83 & 38 & 33 & 47 & $19 ; 80$ \\
\hline GCT main group & 165 & 38 & 32 & 47 & $19 ; 80$ \\
\hline Cohort 2 & 84 & 45 & 36 & 59 & $17 ; 82$ \\
\hline Cohort 3 & 237 & 66 & 53 & 76 & $18 ; 94$ \\
\hline
\end{tabular}

cohort 2 denotes control group consisting of patients with non-neoplastic scrotal diseases; cohort 3 denotes control group 2 consisting of male urologic patients with non-testicular and non-neoplastic diseases

Q1 first quartile, Q3 third quartile 
Table 2 25OHD serum levels (ng/ml) in GCT main group and in controls: frequencies of categories of 25OHD serum levels

\begin{tabular}{|c|c|c|c|c|c|c|}
\hline & Eligible (n) & Normal (n) (\%) & $\begin{array}{l}20-30 \mathrm{ng} / \mathrm{ml} \\
\text { (n) }(\%)\end{array}$ & $\begin{array}{l}10-19 \mathrm{ng} / \mathrm{ml} \\
\text { (n) (\%) }\end{array}$ & $\begin{array}{l}<10 \mathrm{ng} / \mathrm{ml} \\
\text { (n) }(\%)\end{array}$ & $p$-value \\
\hline GCT main group & 165 & $25(15.15 \%)$ & 35 (21.21\%) & $68(41.21 \%)$ & 37 (22.42\%) & \\
\hline Cohort 2 & 84 & 17 (20.2\%) & $22(26.2 \%)$ & $26(31.0 \%)$ & 19 (22.6\%) & \\
\hline Cohort 3 & 237 & 52 (21.9\%) & 57 (24.1\%) & 83 (35.0\%) & 45 (19.0\%) & \\
\hline
\end{tabular}

cohort 2 denotes control group consisting of patients with non-neoplastic scrotal diseases; cohort 3 denotes control group 2 consisting of male urologic patients with non-testicular and non-neoplastic diseases

${ }^{a}$ Kruskal Wallis Test

\section{Evaluation of 25-hydroxyvitamin D serum levels in the various patient populations}

We compared GCT-patients (GCT main group) with controls (Cohorts 2 and 3) quantitatively and qualitatively by analyzing proportions of serum level categories of $25 \mathrm{OHD}$. To look for the hypothesized greater reduction of 25OHD levels in patients with bilateral tumors, we compared the measurements in patients with unilateral GCT to those of patients with bilateral tumors. For this comparison, we only used the measurements at the latest point of time available in the individual patients (GCT main group).

To look for decreases of 25OHD levels subsequent to orchiectomy, we compared preoperative levels (measurement 0) with those measured immediately after surgery (measurement 1) and also with the levels measured at follow-up visits (time-points 2-6). In a first step, we analysed intra-individual changes by including only patients with serial measurements available. For this purpose, we analyzed the median serum levels of the cohorts relating to the postoperative time-points and we also analyzed the frequencies of patients with decreasing and non-changing levels. However, as only few patients were available with more than 3 measurements and particularly with measurements beyond time-point 4, we performed a second analysis by comparing the cohort results available at the six postoperative time-points of measurements with regard to median serum levels and proportions of serum level categories.
In an exploratory approach, we looked to correlations of the 25OHD serum level in the GCT-main group with various parameters. For analysis of testosterone serum levels, we used the following categories of testosterone serum levels: subnormal $(<2.4 \mathrm{ng} / \mathrm{ml})$, low-normal $(2.4-$ $3.2 \mathrm{ng} / \mathrm{ml})$; normal $(3.2-8.7 \mathrm{ng} / \mathrm{ml})$; supranormal $(>8.7$ $\mathrm{ng} / \mathrm{ml}$ ). For analysis of FSH-levels we used the following categories: low $<2 \mathrm{U} / \mathrm{l}$; normal 2.0-11.9 U/l; slightly increased 12.0-15 U/l; highly increased $>15 \mathrm{U} / \mathrm{l}$. To evaluate seasonal influences, the median and mean 25OHD levels in the seasons of the year were compared to each other. To look for associations of 25OHD levels with age, we compared the median serum levels of the following age-categories: $<20$ years; $20-29$ years; $30-39$ years; $40-49$ years; $\geq 50$ years. To look for associations with histology of testicular tumors, we compared the median serum levels of patients with pure seminoma to those with nonseminoma. This latter comparison was done with the baseline measurements and again with the GCT main group.

\section{Statistical methods}

Minimum, $5 \%$ percentile (P5), median, quartiles (Q1, Q3), $95 \%$ percentile (P95) and maximum, interquartile ranges (IQR) and mean (with standard deviation, SD, and $95 \%$ confidence limits) were calculated for the $25 \mathrm{OHD}$ levels in subgroups of GCT patients at the various time points of measurements and in controls. For each subgroup, we also calculated the relative proportions of the 25OHD serum level categories normal,

Table $325 \mathrm{OHD}$ serum levels (ng/ml) in GCT main group and controls

\begin{tabular}{|c|c|c|c|c|c|c|c|c|}
\hline & $\mathrm{n}$ & Min & Q1 & Median & Q3 & Max & Mean & SD \\
\hline GCT main group & 165 & 3.4 & 10.50 & 15.80 & 24.40 & 142 & 19.63 & 15.56 \\
\hline Cohort 2 & 84 & 3.1 & 10.50 & 19.15 & 25.90 & 85.1 & 21.27 & 14.54 \\
\hline Cohort 3 & 237 & 3.4 & 11.00 & 18.90 & 26.50 & 148.1 & 22.30 & 17.38 \\
\hline
\end{tabular}

median median 25OHD serum levels, mean: mean 25OHD serum level values, Q1 first quartile, Q3 third quartile, SD standard deviation

cohort 2 denotes control group consisting of patients with non-neoplastic scrotal diseases; cohort 3 denotes control group 2 consisting of male urologic patients with non-testicular and non-neoplastic diseases

$P=0.1797$ Kruskal Wallis Test for over-all comparison of GCT main group with the two other cohorts 


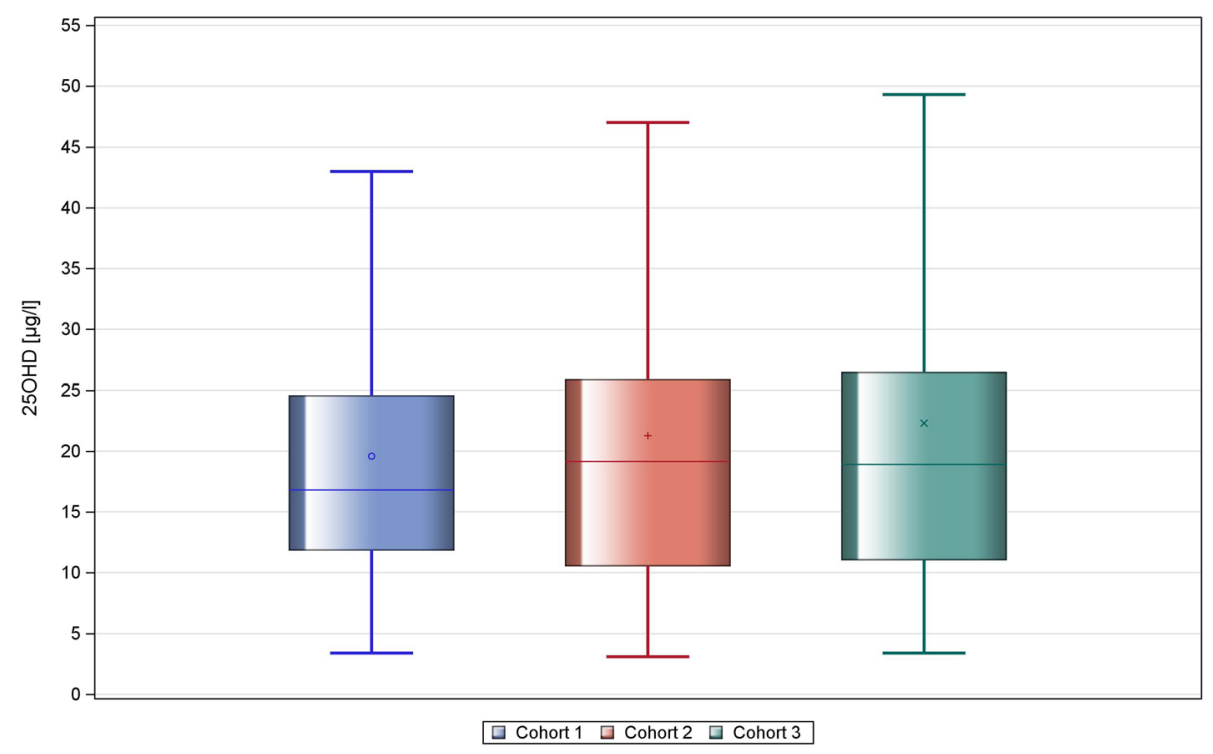

Fig 1 Comparison of serum vitamin D levels of GCT main group with controls. There is no significant difference of median 25OHD levels between the groups. Cohort 1 represents the GCT main group, cohort 2 denotes the first control group with nonneoplastic scrotal diseases. Cohort 3 represents the second control group that comprises of male urologic patients with nontesticular and non-malignant diseases

and S1-S3. Results were documented as box-plot images whenever reasonable. For comparisons of proportions, the chi square tests was used. For comparison of two groups the Mann Whitney -U-test was applied and for more than two groups the Kruskal Wallis test. To increase statistical power by taking into account the correlation between repeated measurements within subjects, the Wilcoxon test and Friedman test were applied to compare two visits and more than two visits, respectively. To test any directional change of 25OHD level categories over time the Jonckhere Terpstra test was applied. P values were explorative, based on a significance level of 0.05. SAS software (version 9.4) was used for all statistical analyses.

\section{Results}

\section{General results}

A total of 501 men had measurements of 25OHD serum levels, thereof 177 patients with GCT (cohort 1; 112 seminoma, 65 nonseminoma), 87 patients with other testicular diseases (cohort 2) and 237 patients with nontesticular, non-neoplastic diseases (cohort 3). Details are given in Table 1. Nine patients had bilateral testicular tumors thereof six with serum levels measured postoperatively (p/o). Preoperative measurements were available in 83 GCT patients, 94 GCT patients were recruited at later points of time with many of whom undergoing repeated measurements. The patient samples at timepoints 1 (immediately $\mathrm{p} / \mathrm{o})-6$ (>24 months $\mathrm{p} / \mathrm{o})$

Table 4 25OHD serum levels (ng/ml) in patients with unilateral and bilateral GCT

\begin{tabular}{|c|c|c|c|c|c|c|c|}
\hline & $\mathrm{n}$ & median & Q1; Q3 & Min; $\max$ & mean & SD & $p$-value \\
\hline Unilateral GCT ${ }^{a}$ & 159 & 15.80 & $10.50 ; 24.40$ & $3.40 ; 142.40$ & 19.62 & 15.63 & \\
\hline \multirow[t]{2}{*}{ Bilateral GCT ${ }^{a}$} & 6 & 14.0 & $9.40 ; 27.30$ & 7.70; 46.70 & 19.85 & 14.84 & \\
\hline & & & & & & & $P=0.8721^{b}$ \\
\hline Cohort 2 & 84 & 19.15 & $10.5 ; 25.9$ & $3.1 ; 85.1$ & 21.27 & 14.54 & \\
\hline \multirow[t]{2}{*}{ Cohort 3} & 237 & 18.9 & $11.0 ; 26.5$ & $3.4 ; 148.1$ & 22.3 & 17.38 & \\
\hline & & & & & & & $P=0.1797^{c}$ \\
\hline
\end{tabular}

Q1 first quartile, Q3 third quartile, SD standard deviation

cohort 2 denotes control group consisting of patients with non-neoplastic scrotal diseases; cohort 3 denotes control group 2 consisting of male urologic patients with non-testicular and non-neoplastic diseases

${ }^{a}$ in each patient, the latest postoperative measurement value available was employed for analysis

${ }^{b}$ Mann Whitney $\mathrm{U}$ test for comparison of unilateral versus bilateral tumors

${ }^{c}$ Kruskal Wallis test for comparison of all cohorts 
Table 5 Shift table: Comparing 25OHD baseline measurement values with measurements at each later time point - intra-individual analysis of complete cases only

\begin{tabular}{lllll}
\hline Time point & $\mathbf{n}^{\mathbf{a}}$ & Decrease $(\mathbf{n} ; \%)$ & No change $(\mathbf{n} ; \%)$ & Increase $(\mathbf{n} ; \%)$ \\
\hline Baseline & 83 & - & $43(75.4 \%)$ & - \\
Immediate p/o & 57 & $13(22.8 \%)$ & $20(45.4 \%)$ & $1(1.8 \%)$ \\
3 months p/o & 44 & $13(29.6 \%)$ & $2(11.8 \%)$ & $11(25.0 \%)$ \\
6 months p/o & 17 & $11(64.7 \%)$ & $1(20.0 \%)$ & $4(23.5 \%)$ \\
12 months p/o & 5 & $3(60.0 \%)$ & $1(20.0 \%)$ \\
\hline
\end{tabular}

Jonckhere-Terpstra test for change over time $p=0.0743$. The last value (12 months $\mathrm{p} / \mathrm{o}$ ) was not included in statistical analysis because of too small numbers p/o postoperatively

anly complete cases were included, i.e. those with serial measurements available

comprised of $84,78,39,26,24$, and 26 measurements, respectively. The GCT main group consisted of 165 patients with 34 (20.6\%), 50 (30.3\%), 27 (16.4\%), 12 (7.2\%), 16 (9.7\%), 26 (15.8\%) having their last measurements at the time-points $1-6$, respectively. In this group, the median measurement was at time point 2 (IQR 2-5).

\section{Comparison of 25-hydroxy vitamin serum levels of GCT patients with controls}

Prior to surgery, $21.7 \%$ of GCT patients were found to have normal serum levels of $25 \mathrm{OHD}$ which is not different from the findings in cohort 2 (20.2\%) and cohort 3 (21.9\%), respectively. The frequencies of 25OHD serum level categories of the GCT main group and the two control groups are listed in Table
2. Statistical comparison did not reveal any significant difference (Kruskal Wallis test $p=0.1615$ ). The calculated median and mean serum levels of the GCT main group and controls are listed in Table 3, and again, no significant differences were found between patients and controls (Fig. 1). Pooling of the two control groups did not change the result $(p=0.706$ Mann Whitney $U$ test, data not shown).

\section{Comparison of unilateral GCT with bilateral GCT}

The median serum 25OHD levels of patients with bilateral GCT and of those with unilateral disease are not significantly different. Details are given in Table 4.

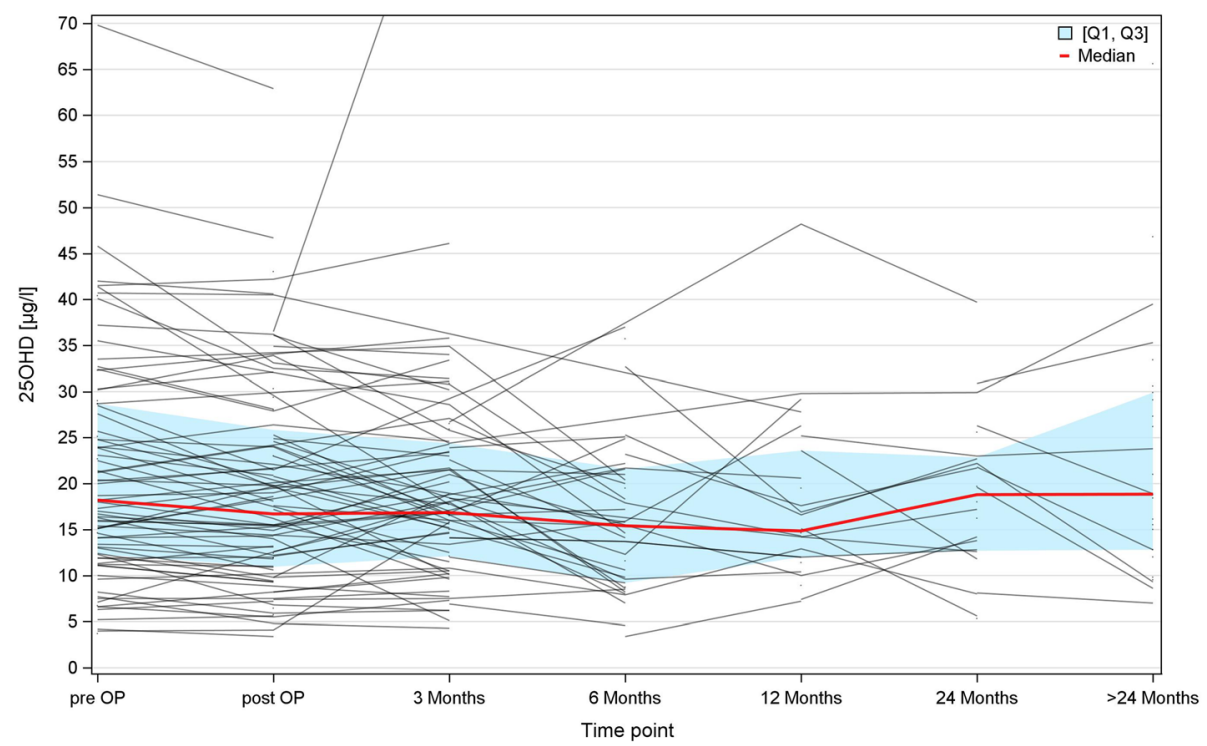

Fig. 2 Longitudinal changes of 25OHD serum levels in individual patients. Each line represents one individual patient. The red line represents the median 25OHD level of all patients eligible at the various points of time. It shows a slight decline from baseline to the 6 months and 12 months time point and a subsequent increase thereafter. Q1 first quartile, Q3 third quartile 
Table 6 Changes of $250 \mathrm{HD}$ levels ( $\mathrm{ng} / \mathrm{ml}$ ) over time. Intra-individual analysis of cases with serial measurements

\begin{tabular}{|c|c|c|c|c|c|}
\hline Time point & Measures & Results per visit & Results at baseline & Results per visit & Changes from baseline \\
\hline \multirow[t]{3}{*}{ preoperative } & $n$ & 83 & & & \\
\hline & Mean (SD) & $21.21(12.29)$ & & & \\
\hline & Median (Q1, Q3) & $18.20(12.30,28.70)$ & & & \\
\hline \multirow[t]{4}{*}{ Immediately p/o } & $n$ & 84 & 57 & 57 & 57 \\
\hline & Mean (SD) & $19.48(11.58)$ & $21.28(13.22)$ & $19.33(12.08)$ & $-1.95(3.40)$ \\
\hline & Median (Q1, Q3) & $16.70(10.95,25.85)$ & $17.00(12.30,27.60)$ & $15.50(10.90,24.10)$ & $-1.10(-4.00,0.10)$ \\
\hline & $p$-value ${ }^{a}$ & & & & 0.3258 \\
\hline \multirow[t]{4}{*}{3 mon p/o } & $n$ & 78 & 44 & 44 & 44 \\
\hline & Mean (SD) & $21.12(18.22)$ & $20.93(10.73)$ & $19.37(9.33)$ & $-1.56(7.51)$ \\
\hline & Median (Q1, Q3) & $16.85(12.10,24.40)$ & $18.45(14.60,28.15)$ & $17.90(12.00,24.50)$ & $0.70(-6.95,3.75)$ \\
\hline & $p$-value ${ }^{a}$ & & & & 0.5482 \\
\hline \multirow[t]{5}{*}{6 mon p/o } & $n$ & 39 & 17 & 17 & 17 \\
\hline & Mean (SD) & $16.28(8.14)$ & 23.79 (9.94) & $16.58(7.62)$ & $-7.21(10.90)$ \\
\hline & Median (Q1, Q3) & $15.40(9.20,21.60)$ & $24.00(16.00,28.50)$ & $15.90(9.80,20.40)$ & $-8.20(-15.20,0.50)$ \\
\hline & $p$-value ${ }^{a}$ & & & & 0.0497 \\
\hline & $p$-value ${ }^{b}$ & & & & 0.0122 \\
\hline
\end{tabular}

p/o postoperatively, mon months, $S D$ standard deviation, $Q 1$ first quartile, $Q 3$ third quartile

${ }^{a}$ Wilcoxon-Test for the comparison of paired measures (baseline with post-OP, baseline with 3 Months and so on)

${ }^{b}$ Friedman-Test for the comparison of the cohort course over time for all measures until 6 Months post-operative visit

\section{Longitudinal changes of 25-hydroxy vitamin D levels}

Of the patients who had serial measurements available, $64.7 \%$ had decreased 25OHD levels 6 months after orchiectomy by comparison with baseline levels (further details in Table 5 and Fig. 2). Accordingly, there is a significant decrease of median serum 25OHD levels from baseline to time-point 3 (6 months $\mathrm{p} / \mathrm{o}$ ), both by pairwise comparing the median levels of baseline with the 6-months measurement (Wilcoxon test, $p=0.0497$ ) and by analyzing the changes of the cohort course over time (Friedman test, $p=0.0122$ ). Details are given in Table 6. Due to low numbers with complete sets of serial measurement at all time points, the serum levels at 12 months are not statistically different from baseline despite their even lower measurement results.

If patients who had measurements available at particular time-points were grouped according to the particular time-points of measurements, no significant change over time was observed regarding the proportions of $25 \mathrm{OHD}$ serum level categories (Table 7 ) with regard to the entire period of observation (Jonckhere-Terpstra test, $p=$ 0.1913). However, if the proportions of categories of time-point 3 (6 months $\mathrm{p} / \mathrm{o})$ are compared to the

Table 7 Changes over time: frequencies of categories of 250HD serum levels at different time points

\begin{tabular}{|c|c|c|c|c|c|c|c|}
\hline Time-point & Eligible (n) & $\begin{array}{l}\text { Normal } \\
\text { (n) }(\%)\end{array}$ & $\begin{array}{l}20-30 \mathrm{ng} / \mathrm{ml} \\
(\mathrm{n})(\%)\end{array}$ & $\begin{array}{l}10-19 \mathrm{ng} / \mathrm{ml} \\
\text { (n) }(\%)\end{array}$ & $\begin{array}{l}<10 \mathrm{ng} / \mathrm{ml} \\
\text { (n) }(\%)\end{array}$ & $p$-value ${ }^{a}$ & $p$-value ${ }^{b}$ \\
\hline 0 (preoperatively) & 83 & $18(21.7 \%)$ & $22(26.5 \%)$ & $30(36.2 \%)$ & $13(15.7 \%)$ & - & - \\
\hline 1 (immediate $\mathrm{p} / \mathrm{o}$ ) & 84 & $15(17.9 \%)$ & $19(22.6 \%)$ & 31 (36.9\%) & 19 (22.6\%) & 0.232 & - \\
\hline 2 (3 months p/o) & 78 & $12(15.4 \%)$ & $20(25.6 \%)$ & 35 (44.9\%) & $11(14.1 \%)$ & 0.4397 & - \\
\hline 3 (6 months p/o) & 39 & $3(7.7 \%)$ & $10(25.6 \%)$ & 14 (35.9\%) & $12(30.8 \%)$ & 0.0270 & 0.0737 \\
\hline 4 (12 months p/o) & 26 & $1(3.9 \%)$ & $7(26.9 \%)$ & $15(57.7 \%)$ & $3(11.5 \%)$ & 0.1605 & 0.0559 \\
\hline 5 (24 months $\mathrm{p} / \mathrm{o}$ ) & 24 & $2(8.3 \%)$ & $8(33.3 \%)$ & $10(41.7 \%)$ & $4(16.7 \%)$ & 0.3905 & 0.0793 \\
\hline 6 (>24 months p/o) & 26 & $6(23.1 \%)$ & $6(23.1 \%)$ & $9(34.6 \%)$ & $5(19.2 \%)$ & 0.8444 & 0.1913 \\
\hline
\end{tabular}


Table 8 Changes of 25OHD serum levels ( $\mathrm{ng} / \mathrm{ml}$ ) over time: median and mean values at different time points

\begin{tabular}{|c|c|c|c|c|c|c|c|c|c|c|c|}
\hline Time-point of Measurement & $\mathbf{n}$ & MIN & P5 & Q1 & MEDIAN & Q3 & P95 & MAX & MEAN & LCLM & UCLM \\
\hline 0 & 83 & 3.7 & 6.3 & 12.30 & 18.20 & 28.70 & 41.5 & 69.8 & 21.21 & 18.53 & 23.90 \\
\hline 1 & 84 & 3.4 & 5.6 & 10.95 & 16.70 & 25.85 & 40.6 & 62.9 & 19.48 & 16.97 & 22.0 \\
\hline 2 & 78 & 4.3 & 6.2 & 12.10 & 16.85 & 24.40 & 35.8 & 142.4 & 21.12 & 17.01 & 25.23 \\
\hline 3 & 39 & 3.4 & 4.6 & 9.20 & 15.40 & 21.60 & 35.7 & 37.0 & 16.28 & 13.64 & 18.92 \\
\hline 4 & 26 & 7.2 & 7.4 & 12.00 & 14.85 & 23.60 & 29.8 & 48.2 & 17.92 & 14.24 & 21.60 \\
\hline 5 & 24 & 5.3 & 5.6 & 12.70 & 18.80 & 22.85 & 30.9 & 39.7 & 18.61 & 15.05 & 22.18 \\
\hline 6 & 26 & 7.0 & 8.6 & 12.80 & 18.85 & 29.90 & 46.8 & 65.6 & 22.81 & 17.30 & 28.32 \\
\hline
\end{tabular}

P5 5\% percentile; Q1 first quartile; Q3 third quartile; P95 95\% percentile; LCLM Lower 95\% confidence limit of mean UCLM upper $95 \%$ confidence limit of mean

distribution of categories at baseline, there is a significant decrease of proportions with normal levels (Kruskal Wallis test, $p=0.0270$ ) with only $7.7 \%$ of patients having normal 25OHD serum levels at this point of time. Thereafter, there is a further slight decrease of the proportion of normal levels until the 12 months time-point followed by a recovery to normal after 2 years. Details are given in Table 7.

Table 8 and Fig. 3 provide measurement results of the patient cohorts with available 25OHD measurements at the various time-points. Again, the median and mean serum levels decrease after orchiectomy to reach a nadir at 6 months (mean) and 12 months (median) followed by an increase reaching even higher levels than preoperatively at the last time-point of measurement.

\section{Results of exploratory search for associations}

The results of the exploratory analysis of possible associations of $25 \mathrm{OHD}$ serum levels with various clinical parameters are listed in Tables 9, 10, 11, 12 and 13, and Fig. 4. Briefly, significantly higher 25OHD levels are observed in quarters 2 and 3 of the year (April to September,) than in the other seasons (Table 11, Fig. 4), whereas no significant associations were found with categories of testosterone levels, categories of FSH, age categories, and histologic subgroups of GCT (Kruskal Wallis test, all analyses $\mathrm{p}>0.05$ ).

\section{Discussion}

The central result of the present study is that no significant reduction of 25-hydroxyvitamin D serum levels could be detected in patients with testicular

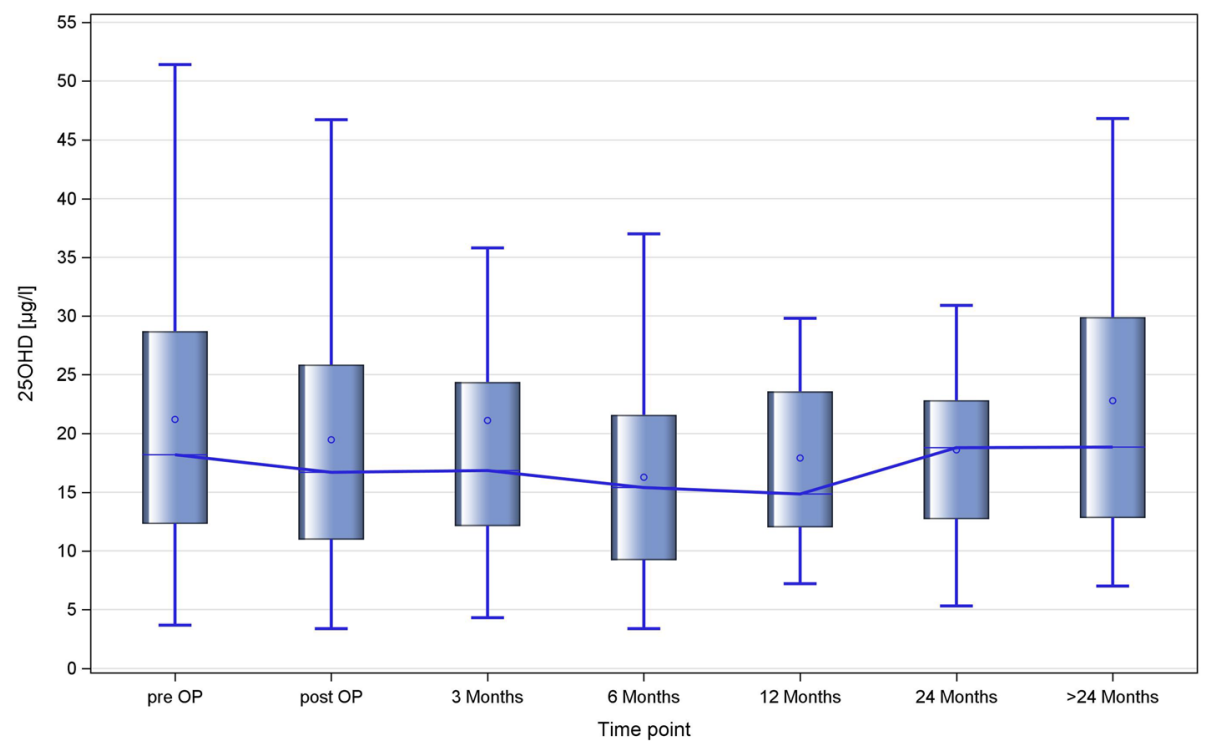

Fig. 3 Longitudinal changes of serum 25OHD levels in GCT patients (box plot image). Each box denotes the median 25OHD serum levels with interquartile ranges in cohorts at consecutive time-points. The connecting line demonstrates a decrease of levels reaching a nadir at the 6 months time point and subsequent rise of levels thereafter. Preop: preoperative measurement, post-op measurement after orchiectomy 
Table 9 25OHD levels in relation to serum testosterone (GCT main group)

\begin{tabular}{|c|c|c|c|c|}
\hline \multirow[b]{2}{*}{ categories of testosterone levels $(\mathrm{ng} / \mathrm{ml})$} & \multirow[b]{2}{*}{$\mathbf{n}$} & \multicolumn{2}{|c|}{ 25OHD serum level $(\mathrm{ng} / \mathrm{ml})$} & \multirow[b]{2}{*}{$p$-value } \\
\hline & & Median (Q1;Q3) & Mean (SD) & \\
\hline Subnormal $(<2.4)$ & 19 & $15.80(9.60,35.70)$ & $22.23(16.52)$ & \\
\hline Low normal $(2.4-<3.2)$ & 19 & $16.20(9.30,21.00$ & $17.63(9.49$ & \\
\hline Normal $(3.2-<8.7)$ & 114 & $16.75(11.00,25.60)$ & $20.34(16.78)$ & \\
\hline Supranormal (>8.7) & 13 & $12.00(9.20,12.80)$ & $12.59(5.92)$ & \\
\hline
\end{tabular}

Q1 first quartile, Q3 third quartile, $S D$ standard deviation

aruskal Wallis test

germ cell tumors neither at the time of diagnosis nor in the long-term course. However, there appears to be a transient reduction of $25 \mathrm{OHD}$ serum levels during the first year after orchiectomy followed by a recovery after 2 years. In GCT patients, 25OHD serum levels are associated with season, but no significant associations were found with testosterone levels, FSH levels, age and histology of the testicular neoplasm.

The presence of enzymes CYP2R1 and CYP27B1 and the detection of vitamin $\mathrm{D}$ receptor expression in testicular tissue as well as evidence for clinically relevant vitamin D deficiency in hypogonadal men [17, 23, 2729] suggested a prominent role of the testis in the metabolism of this vitamin $[15,16,19,24]$. Accordingly, three clinical studies reported higher incidences of subnormal 25OHD serum levels in patients orchiectomized for GCT particularly during long-term follow-up [24-26]. However, the results of the present investigation are clearly at variance with these studies. The reasons for the conflicting results are not clear, but sample sizes and methodological discrepancies could account for disconformities. The three previous studies comprised of rather small sample sizes of 15,61 , and 82 patients, respectively, whereas our GCT main group had as many as 165 patients. Thus, chance effects might have influenced the results of previous studies. Accordingly, the p-values in one of the studies were just slightly below the level of significance [25]. Furthermore, one study based the results only on the reference limits of the 25OHD serum test without a formal control group [26]. However, subnormal levels of 25OHD are observed in up to $40 \%$ of the general population in western countries [30] which is even worse in the present study where we found normal levels of only 20.2 and $21.9 \%$, respectively, in the two control groups.

Foresta et al. suggested that total loss of testicular parenchyma by bilateral orchiectomy would result in a significant reduction of vitamin $\mathrm{D}$ metabolizing capacity and might thus cause decreased serum levels [6]. That hypothesis is quite appealing because it would be in line with the observation of low 25OHD levels in hypogonadal men [23], but it is based on only 15 patients. Our sample size is even smaller with respect to the subgroup of bilateral GCT, but we did not observe significantly different 25OHD serum levels among GCT patients with bilateral and unilateral disease and controls. No other study has addressed the vitamin D status in patients with total loss of testicular tissue so far. Therefore, no final conclusion can be drawn to date because the numbers of patients tested are clearly too small.

Although we did not observe a permanent reduction of 25OHD levels after orchiectomy, we noted a significant and continuous decrease postoperatively

Table 10 25OHD levels in relation to Follicle Stimulating hormone (FSH) levels (GCT main group)

\begin{tabular}{llll}
\hline categories of FSH levels & $\mathbf{n}$ & $\begin{array}{l}\text { 25OHD serum levels }(\mathbf{n g} / \mathbf{m l}) \\
\text { Median }(\mathbf{Q} 1 ; \mathbf{Q 3})\end{array}$ & Mean $(\mathrm{SD})^{\mathbf{p}}$ \\
\hline Low $(<2 \mathrm{U} / \mathrm{l})$ & 8 & $11.95(10.70,16.35)$ & $13.70(6.81)$ \\
normal $(2-11.9 \mathrm{U} / \mathrm{l})$ & 88 & $15.45(9.80,23.60)$ & $19.88(18.39)$ \\
Slightly elevated $(12-15 \mathrm{U} / \mathrm{l})$ & 18 & $16.20(11.00,19.70)$ & $15.89(7.24)$ \\
Highly elevated $(>15 \mathrm{U} / \mathrm{l})$ & 50 & $17.45(12.00,28.10)$ & $21.39(13.05)$
\end{tabular}


Table $11250 H D$ levels in relation to quarter of the year (GCT main group)

\begin{tabular}{|c|c|c|c|c|}
\hline \multirow[b]{2}{*}{ categories } & \multirow[b]{2}{*}{$\mathbf{n}$} & \multicolumn{2}{|c|}{$250 H D$ serum levels $(\mathrm{ng} / \mathrm{ml})$} & \multirow[b]{2}{*}{$p$-value ${ }^{a}$} \\
\hline & & Median (Q1;Q3) & Mean (SD) & \\
\hline Jan - Mar & 58 & $11.80(8.60,16.90)$ & $14.34(8.23)$ & \\
\hline Apr - Jun & 34 & $17.90(11.60,24.30)$ & $18.56(9.05)$ & \\
\hline Jul - Sep & 37 & $23.50(15.60,31.10)$ & $25.84(14.93)$ & \\
\hline Oct - Dec & 36 & $15.50(10.70,23.80)$ & $22.79(24.87)$ & \\
\hline
\end{tabular}

Q1 first quartile, Q3 third quartile, $S D$ standard deviation ${ }^{\text {aKruskal Wallis test }}$

during the first year reaching a nadir between 6 and 12 months after surgery. Thereafter, the median levels as well as the proportion of normal levels raised again to reach levels equivalent to preoperative findings and to controls. This observation is unique so far since none of the previous studies with GCT patients had examined preoperative 25OHD levels and looked to these patients at subsequent visits. Our finding is statistically significant and it is methodologically sound because it was obtained in an analysis employing exclusively individual patients with serial measurements. The significant decrease was confirmed by an analysis using cohorts comprising of all patients with available measurements at the various time-points. These subgroups consisted of varying patient compositions. Thus, the significant decrease of 25OHD serum levels during the first year after orchiectomy is based on two methodological approaches. Yet, the results still rest on small sample sizes and clearly need further confirmation.

Our finding of a transient decrease of 25OHD serum levels subsequent to orchiectomy would be in line with the hypothesis that testicular tissue may play an important role in the metabolism of vitamin D. A probable explanation for the recovery of $25 \mathrm{OHD}$ levels after two years of time, would be that the testis is obviously not an essential site of vitamin D biosynthesis and other organs holding the hydroxylases CYP2R1 and CYP27B1 (e.g. liver, kidneys) will compensate the loss of testicular tissue after some time. This hypothesis would accord with animal experiments that had revealed an increased synthesis of CYP2R1 in the liver after loss of both testes $[18,20]$. Another hypothetic explanation would be that the remaining testicle could increase its particular metabolic activity and might thus compensate the loss of one testis.

In our exploratory analysis of associations of parameters with 25OHD serum levels, we confirmed that significantly higher serum levels are found in April to September than in the first and fourth quarter. This result is completely in line with current knowledge [7, $9,22]$, and it reflects the impact of more sun-light in spring and summer which is required for the very first step of vitamin D activation in the skin [8, 18]. Noteworthy, we found no association of 25OHD serum levels with testosterone serum levels although such an association had been suggested by investigations of infertile men [22, 23, 29, 31-33]. In GCT patients, one small study found an association of testosterone levels with 25OHD serum levels [25], but one other study reported conflicting results [26]. In view of the present data, the weight of evidence is probably in favor of a null association of $25 \mathrm{OHD}$ levels with testosterone status.

Limitations of the present studies relate to small patient numbers in several subgroups at different timepoints despite the acceptable over-all sample size. Also, the varying compositions of the subgroups at the various time-points do certainly represent a weakpoint. A confounding effect could result from different median ages of the GCT patients and the two control groups. However, that effect is probably low, because we did not note an association of age with

Table 12 25OHD levels in relation to patient's age (GCT main group)

\begin{tabular}{llll}
\hline Age categories & $\mathbf{n}$ & $\begin{array}{l}\text { 25OHD serum levels }(\mathbf{n g} / \mathbf{m l}) \\
\text { Median }(\mathbf{Q} \mathbf{1} \mathbf{Q 3})\end{array}$ & Mean $(\mathrm{SD})$ \\
\hline$<20 \mathrm{yrs}$ & 2 & $29.50(25.60,33.40)$ & $29.50(5.52)$ \\
$20-29 \mathrm{yrs}$ & 22 & $11.25(8.50,18.30)$ & $13.98(7.59)$ \\
$30-39 \mathrm{yrs}$ & 67 & $15.20(10.60,22.70)$ & $20.80(20.42)$ \\
$40-49 \mathrm{yrs}$ & 45 & $17.00(9.40,26.30)$ & $19.60(10.95)$ \\
$>50 \mathrm{yrs}$ & 29 & $16.90(12.00,24.60)$ & $20.59(12.88)$
\end{tabular}


Table $1325 \mathrm{OHD}$ levels in relation to histology of primary tumor

\begin{tabular}{|c|c|c|c|c|}
\hline \multirow[b]{2}{*}{ Histologic subgroup } & \multirow[b]{2}{*}{$\mathbf{n}$} & \multicolumn{2}{|c|}{$250 H D$ serum levels $(\mathrm{ng} / \mathrm{ml})$} & \multirow[b]{2}{*}{$p$-value ${ }^{a}$} \\
\hline & & Median (Q1; Q3) & Mean (SD) & \\
\hline Seminoma, lav & 101 & $16.60(10.50,24.60)$ & $20.18(16.72)$ & \\
\hline \multirow[t]{2}{*}{ Nonseminoma, lav } & 64 & $14.80(10.50,23.55)$ & $18.77(13.60)$ & \\
\hline & & & & 0.5306 \\
\hline Seminoma, baseline & 60 & $18.45(12.75,28.70)$ & $21.44(12.53)$ & \\
\hline \multirow[t]{2}{*}{ Nonseminoma, baseline } & 23 & $18.00(11.30,27.60)$ & $20.63(11.87)$ & \\
\hline & & & & 0.8547 \\
\hline
\end{tabular}

lav Latest available value in individual patients

Q1 first quartile, Q3 third quartile, SD standard deviation

arruskal Wallis test

25OHD levels as reported in the exploratory search section. The seasonal variation of 25OHD serum levels might have influenced our results, particularly the findings of serum level changes over time. However, the decrease of 25OHD levels was observed after an interval of 6-12 months in individual patients and seasons had changed several times during the individual observation periods. Also, seasonal variation is present in both patients and controls and as all subjects were concurrently recruited during the two years study period, this factor should not considerably affect the comparisons of patients with controls. The effects of additional treatment procedures were not accounted for. However, as additional procedures had been applied mostly in nonseminomas and as there was no significant difference between seminomas and nonseminomas, the confounding effect of additional treatment is probably low. Finally, the majority of patients were evaluated during the first two years after orchiectomy. Thus, our data do not allow for a clear conclusion regarding the developments of 25OHD levels in a truly long-term course.

\section{Conclusions}

The hypothesis of a vitamin D deficiency in survivors of testicular GCT is not supported by the results of this study. However, we detected a transient decrease of 25OHD serum levels during the first year after orchiectomy with a recovery after 2 years. Thus, a minor role of the testis in the metabolism of vitamin

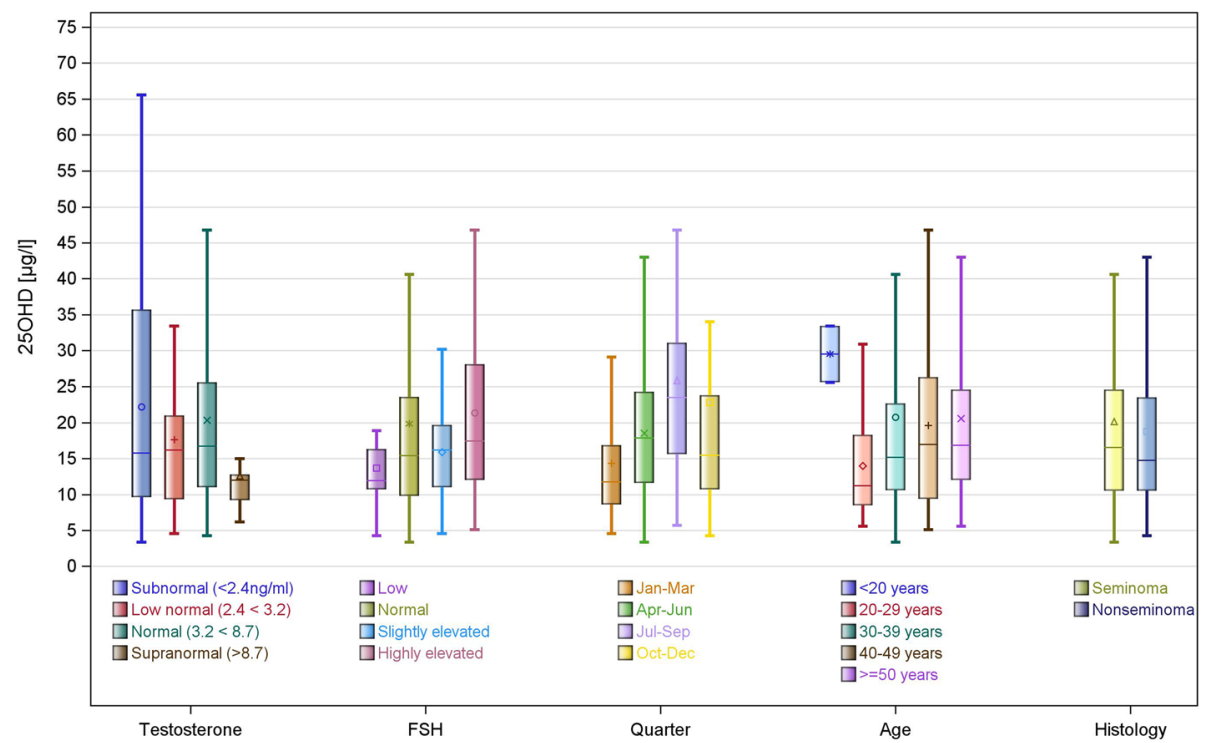

Fig. 4 Possible associations of serum 25OHD levels with clinical factors. Box-plots of categories of serum levels of testosterone and FSH, of age, season, and histology of GCT. A significant association of $25 \mathrm{OHD}$ serum levels was only detected with quarter of the year. Ranges of FSH serum levels: low < $2 \mathrm{U} /$; n normal 2.0 - $11.9 \mathrm{U} /$ /; slightly increased 12.0 - $15 \mathrm{U} /$, highly increased $>15 \mathrm{U} / \mathrm{I}$ 
D seems still conceivable, but obviously, loss of testicular tissue does not necessarily result in clinically relevant vitamin D deficiency.

\section{Abbreviations}

GCT: germ cell tumor; 25OHD: 25-hydroxy vitamin D; FSH: follicle stimulating hormone; p/o: postoperatively; IQR: interquartile range; SD: standard deviation

\section{Acknowledgements}

The authors are grateful to the laboratory staff of the Medilys Laborgesellschaft $\mathrm{mbH}$ for technical assistance upon handling and processing the blood samples.

\section{Authors' contributions}

KPD and HI conceived the study; OA and KPD gathered and compiled the clinical data; KMO supervised the laboratory analyses; UP performed statistical analysis; HI, CW, UP, and KPD accomplished analysis and interpretation of data; CW, OA, and KPD were directly responsible for patient care; all authors read and approved the final manuscript.

\section{Funding}

The present study did not receive any funding.

\section{Availability of data and materials}

The datasets used and/or analyzed during the current study are available from the corresponding author on reasonable request.

\section{Declarations}

\section{Ethics approval and consent to participate}

Ethical approval was waived by enquiry to local Ethical Committee ((Ärztekammer Hamburg, PV7288, June 20, 2020) because only anonymized data obtained during routine clinical care were employed for investigation. All study activities had been conducted according to the Declaration of Helsinki of the World Medical Association (as amended by the 64th General Assembly, 2013)

\section{Consent for publication}

Not applicable, the manuscript does not contain any individual personal data.

\section{Competing interests}

The authors declare that they have no competing interests.

\section{Author details}

'Department of Urology, Testis Cancer Unit, Asklepios Klinik Altona, Paul Ehrlich Strasse 1, Hamburg, Germany. ${ }^{2}$ Institut für Medizinische Biometrie und Statistik, Zentrum für Experimentelle Medizin, Universitätsklinikum Eppendorf, Hamburg, Germany. ${ }^{3}$ Medilys Laborgesellschaft mbH, Hamburg, Germany. ${ }^{4}$ Universitätsklinikum Eppendorf, Martini Klinik Hamburg, Germany.

Received: 30 December 2020 Accepted: 20 April 2021

Published online: 10 June 2021

\section{References}

1. Scott AR, Stoltzfus KC, Tchelebi LT, Trifiletti DM, Lehrer EJ, Rao P, et al. Trends in Cancer Incidence in US Adolescents and Young Adults, 19732015. JAMA Netw Open. 2020;3(12):e2027738. https://doi.org/10.1001/jama networkopen.2020.27738.

2. Cheng L, Albers P, Berney DM, Feldman DR, Daugaard G, Gilligan T. et al.: Testicular cancer. Nat Rev Dis Primers. 2018:4(1):29.

3. Lauritsen J, Hansen MK, Bandak M, Kreiberg MB, Skøtt JW, Wagner T, et al Cardiovascular Risk Factors and Disease After Male Germ Cell Cancer. J Clin Oncol. 2020;38:584-92.

4. Fung C, Dinh PJ, Ardeshir-Rouhani-Fard S, Schaffer K, Fossa SD, Travis LB. Toxicities Associated with Cisplatin-Based Chemotherapy and Radiotherapy in Long-Term Testicular Cancer Survivors. Adv Urol. 2018;2018:8671832.

5. Agrawal V, Dinh PCJ, Fung C, Monahan PO, Althouse SK, Norton K, et al. Adverse Health Outcomes Among US Testicular Cancer Survivors
After Cisplatin-Based Chemotherapy vs Surgical Management. JNCI Cancer Spectr. 2019;4(2):pkz079. https://doi.org/10.1093/jncics/pkz1079 eCollection 2020 Apr.

6. Foresta C, Selice R, Di Mambro A, Strapazzon G. Testiculopathy and vitamin D insufficiency. Lancet. 2010;376(9749):1301.

7. Holick MF. Vitamin D deficiency. N Engl J Med. 2007;357(3):266-81.

8. Zhang R, Naughton DP. Vitamin D in health and disease: current perspectives. Nutr J. 2010;9:65

9. Patseadou M, Haller DM. Vitamine D chez les adolescents: résumé des recommandations pour la pratique Clinique [Vitamin D in adolescents: summarizing guidelines for general practice]. Rev Med Suisse. 2020;16(691): 778-83.

10. Blomberg Jensen $M$, Jørgensen A, Nielsen JE, Bjerrum PJ, Skalkam M, Petersen $\mathrm{JH}$, et al. Expression of the vitamin D metabolizing enzyme CYP24A1 at the annulus of human spermatozoa may serve as a novel marker of semen quality. Int J Androl. 2012;35(4):499-510.

11. Christakos S, Ajibade DV, Dhawan P, Fechner AJ, Mady L. Vitamin D: metabolism. Endocrinol Metab Clin North Am. 2010;39(2):243-53.

12. Willemse PM, Hamdy NA, de Kam ML, Burggraaf J, Osanto S. Changes in bone mineral density in newly diagnosed testicular cancer patients after anticancer treatment. J Clin Endocrinol Metab. 2014;99(11):4101-418.

13. Henry HL, Norman AW. Vitamin D: metabolism and biological actions. Annu Rev Nutr. 1984:4:493-520.

14. Bøllehuus Hansen L, Rehfeld A, de Neergaard R, Nielsen JE, Iversen LH, Boisen IM, et al. Selection of High-Quality Spermatozoa May Be Promoted by Activated Vitamin D in the Woman. J Clin Endocrinol Metab. 2017;102(3): 950-61.

15. Blomberg Jensen M, Nielsen JE, Jørgensen A, Rajpert-De Meyts E, Kristensen DM, Jørgensen $\mathrm{N}$, et al. Vitamin D receptor and vitamin D metabolizing enzymes are expressed in the human male reproductive tract. Hum Reprod. 2010;25(5):1303-11.

16. de Angelis C, Galdiero M, Pivonello C, Garifalos F, Menafra D, Cariati F, et al. The role of vitamin $D$ in male fertility: A focus on the testis. Rev Endocr Metab Disord. 2017;18(3):285-305.

17. Anagnostis $P$, Karras $S$, Goulis DG. Vitamin D in human reproduction: a narrative review. Int J Clin Pract. 2013:67(3):225-135.

18. Blomberg Jensen M. Vitamin D and male reproduction. Nat Rev Endocrinol. 2014:10(3):175-118.

19. Bremmer F, Thelen P, Pottek T, Behnes CL, Radzun HJ, Schweyer S. Expression and function of the vitamin $D$ receptor in malignant germ cell tumour of the testis. Anticancer Res. 2012;32(1):341-9.

20. Addya S, Zheng YM, Shayiq RM, Fan JY, Avadhani NG. Characterization of a female-specific hepatic mitochondrial cytochrome P-450 whose steady-state level is modulated by testosterone. Biochemistry. 1991;30(34):8323-830.

21. Wehr E, Pilz S, Boehm BO, März W, Obermayer-Pietsch B. Association of vitamin D status with serum androgen levels in men. Clin Endocrinol (Oxf). 2010:73(2):243-8.

22. Lerchbaum E, Obermayer-Pietsch B. Vitamin D and fertility: a systematic review. Eur J Endocrinol. 2012:166(5):765-78.

23. Lee DM, Tajar A, Pye SR, Boonen S, Vanderschueren D, Bouillon R, et al. Association of hypogonadism with vitamin D status: the European Male Ageing Study. Eur J Endocrinol. 2012;166(1):77-85.

24. Foresta C, Strapazzon G, De Toni L, Perilli L, Di Mambro A, Muciaccia B, et al. Bone mineral density and testicular failure: evidence for a role of vitamin $D$ 25-hydroxylase in human testis. J Clin Endocrinol Metab. 2011;96(4):E646-52

25. Schepisi G, De Padova S, Scarpi E, Lolli C, Gurioli G, Menna C, et al. Vitamin D status among long-term survivors of testicular cancer. Oncotarget. 2017: 8(22):36780-6.

26. Nappi L, Ottaviano M, Rescigno P, Fazli L, Gleave ME, Damiano V, et al. Long term deficiency of vitamin $D$ in germ cell testicular cancer survivors. Oncotarget. 2018;9(30):21078-85.

27. Habib FK, Maddy SQ, Gelly KJ. Characterisation of receptors for 1,25dihydroxyvitamin D3 in the human testis. J Steroid Biochem. 1990;35(2): 195-9.

28. Corbett ST, Hill O, Nangia AK. Vitamin D receptor found in human sperm. Urology. 2006;68(6):1345-9.

29. Cito G, Cocci A, Micelli E, Gabutti A, Russo Gl, Coccia ME, et al. Vitamin D and male fertility: An updated review. World J Mens Health. 2020; 38(2):164-77.

30. Zittermann A. The estimated benefits of vitamin D for Germany. Mol Nutr Food Res. 2010;54(8):1164-71. 
31. Nimptsch K, Platz EA, Willett WC, Giovannucci E. Association between plasma 25-OH vitamin D and testosterone levels in men. Clin Endocrinol (Oxf). 2012;77(1):106-12.

32. Hammoud AO, Meikle AW, Peterson CM, Stanford J, Gibson M, Carrell DT. Association of 25-hydroxy-vitamin D levels with semen and hormonal parameters. Asian J Androl. 2012;14(6):855-9.

33. Tak YJ, Lee JG, Kim YJ, Park NC, Kim SS, Lee S, et al. Serum 25-

hydroxyvitamin D levels and testosterone deficiency in middle-aged Korean men: a cross-sectional study. Asian J Androl. 2015;17(2):324-8.

\section{Publisher's Note}

Springer Nature remains neutral with regard to jurisdictional claims in published maps and institutional affiliations.

Ready to submit your research? Choose BMC and benefit from:

- fast, convenient online submission

- thorough peer review by experienced researchers in your field

- rapid publication on acceptance

- support for research data, including large and complex data types

- gold Open Access which fosters wider collaboration and increased citations

- maximum visibility for your research: over $100 \mathrm{M}$ website views per year

At BMC, research is always in progress.

Learn more biomedcentral.com/submissions 